\title{
Effects of short-term injection of gonadotrophins on ovarian follicle development in hypogonadal $(\mathrm{hpg})$ mice
}

\author{
D. M. G. Halpin $†$ and H. M. Charlton \\ Department of Human Anatomy, University of Oxford, South Parks Road, Oxford OX1 3QX, U.K.
}

\begin{abstract}
Summary. Twice daily injections of purified ovine and human FSH were used to investigate the control of ovarian follicle development in hypogonadotrophic hypogonadal ( $h p g$ ) mice. Treatment for 5 days with doses greater than $3 \mu \mathrm{g}$ resulted in a significant increase in the total number of growing follicles and the development of antral follicles. This was associated with increases in uterine weights and vaginal opening, indicating that steroidogenesis had also been stimulated. Further studies of the effects of combined injections of FSH and LH, linked with morphological analysis of ovarian interstitial cells, suggested that any contribution of background or contaminating LH to the effects of the FSH injections was minimal. It therefore appears that, in mice, FSH alone is capable of stimulating an increase in the initiation of follicle growth, of triggering the development of antral follicles, and supporting ovarian steroidogenesis.
\end{abstract}

Key'words: ovary; ovarian follicle; FSH; steroidogenesis; hypogonadism

\section{Introduction}

In adult mice, ovarian follicular development proceeds against a background of cyclical changes in the plasma concentrations of gonadotrophins, which are thought to control this process (Richards, 1980). From a mathematical analysis of ovarian follicle dynamics in normal and in GnRH-deficient hypogonadal $(\mathrm{hpg})$ mice we have suggested that gonadotrophins act at several stages during the development of ovarian follicles (Halpin et al., 1986a), but these studies could not distinguish separate effects of FSH and $\mathbf{L H}$. In fact, there is still considerable uncertainty over the separate roles of $\mathrm{LH}$ and FSH in the control of follicle development and in particular there is conflicting evidence about the roles of these hormones in the stimulation of development of antral follicles.

In hypogonadal mice endogenous FSH and $\mathrm{LH}$ are insufficient to stimulate preovulatory follicle development and the size of the growing follicle population is reduced (Halpin et al., 1986b). These mice can therefore be used to study the effects of gonadotrophins on follicular development.

\section{Materials and Methods}

The mice used were hpg mutants or normal animals reared in the Department of Human Anatomy, Oxford, from an original stock provided by the MRC Radiobiology Unit, Harwell. Females were weaned at $18-20$ days of age and maintained as described by Halpin et al. (1986b).

Three preparations of FSH with different biological activity and purity were used. NIH-oFSH-S13 is a preparation of sheep FSH kindly supplied by NIADDK, NIH, Bethesda, MD, U.S.A. It has a potency of 15 NIHFSH-Sl units/mg (i.e. 15 i.u./mg) as determined by the hCG augmentation bioassay of Steelman \& Pohley (1953) and an LH contamination of $0.05 \mathrm{NIH}-\mathrm{LH}-\mathrm{S} 1 \mathrm{units} / \mathrm{mg}$ as determined by the ovarian ascorbic acid-depletion bioassay (Parlow, 1961). Its contamination with TSH, growth hormone and prolactin was less than $0 \cdot 1 \%$ by weight (NIADDK Data Sheet). Another preparation of sheep FSH was also supplied by NIADDK; however, NIH-oFSH-S15 is more potent than SI3 with an activity of $20 \mathrm{NIH}-\mathrm{FSH}-\mathrm{Sl}$ units $/ \mathrm{mg}$ (i.e. $20 \mathrm{i} . \mathrm{u} . / \mathrm{mg}$ ) as determined by the hCG augmentation bioassay. It also contains slightly less LH than S13 with a contamination of $0.04 \mathrm{NIH}-\mathrm{LH}-\mathrm{S} 1 \mathrm{units} / \mathrm{mg}$ (ovarian ascorbic acid-depletion bioassay) and its contamination with TSH, growth hormone and prolactin was again $<0.1 \%$ by weight (NIADDK Data Sheet). LER $8 / 116 \mathrm{hFSH}$ is a preparation of human FSH kindly supplied by Professor L. E. Reichert, Department of Biochemistry, Albany Medical College, Albany, NY, U.S.A., which has been

†Present address: Department of Obstetrics and Gynaecology, St Thomas's Hospital, London SE1 7EH, U.K. 
enzymically treated to reduce the LH contamination (Reichert, 1967). LER $8 / 116$ has a potency of $35 \mathrm{NIH}-\mathrm{FSH}-\mathrm{S} 1$ units $/ \mathrm{mg}$ (i.e. 35 i.u. $/ \mathrm{mg}$ ) as determined by the hCG augmentation bioassay, and it has an extremely low contamination with $\mathrm{LH}$, estimated at $5.2 \mathrm{i} . \mathrm{u}$./mg by the ventral prostate weight gain bioassay (Greep et al., 1942) equivalent to less than 0.01 NIH-LH-S1 units/mg (L. E. Reichert, personal communication). Sheep LH, NIH-oLH-S24, again kindly supplied by NIADDK, was used for all the experiments involving LH. This has a potency of 2.3 NIH-LH-S1 units/mg as determined by the ovarian ascorbic acid-depletion bioassay, and contains $<0.5 \%$ FSH by weight (NIADDK Data Sheet).

The hormone for injection was made up at the appropriate concentration in $0.9 \%(\mathrm{w} / \mathrm{v}) \mathrm{NaCl}$ and injections were given subcutaneously in the nape of the neck. Groups of $h p g$ females aged between 90 and 130 days were injected twice daily (at 10:00 and 22:00 h) for 4 or 5 days and vaginal smears were taken daily for each animal once vaginal opening had occurred. The morning after the last day of treatment, the animals were anaesthetized with $0.4 \mathrm{ml}$ urethane solution ( $1 \mathrm{~g}$ ethyl carbamate $/ \mathrm{kg}$ administered i.p. as a $10 \%$ solution in $0.9 \% \mathrm{NaCl}$ ). The ovaries were exposed via a flank incision, the ovarian blood vessels clamped and the ovaries removed and dissected free of surrounding fat. One ovary was fixed in $2 \%$ glutaraldehyde for ultrastructural studies and the other was fixed in Bouin's fluid for light microscopy. The uterus was also removed, dissected free of fat, fixed in Bouin's fluid and weighed after fixation.

The ovaries for light microscopy were embedded in paraffin wax and sectioned serially at $7 \mu \mathrm{m}$. The sections were stained with haematoxylin and eosin and for each animal the total number of follicles of each type was determined using the scheme of Pedersen \& Peters (1968) as described previously (Halpin et al., 1986b). Type 3b follicles are the earliest growing follicles and consist of an oocyte surrounded by a single layer of between 20 and 60 granulosa cells, whilst types $4,5 \mathrm{a}$ and $5 \mathrm{~b}$ contain increasing numbers of granulosa cells in multiple layers. Type 6 follicles contain scattered areas of follicular fluid and are thus the earliest antral follicles. The antrum is fully formed in type 7 follicles, but although the cumulus oophorus has formed there is no stalk, which is a feature of fully ripe, type 8 follicles.

The ovaries for ultrastructural studies were washed in phosphate-buffered saline, post-fixed in $2 \%$ osmium tetroxide, washed, dehydrated through a graded series of alcohols, passed through propylene oxide and embedded in Araldite (Taab Laboratories, Reading, Berks, U.K.). Sections for transmission electron microscopy were cut on a Reichert OM U2 ultramicrotome and stained with saturated methanolic uranyl acetate and lead citrate.

Granulosa cell area and size of lipid droplets in interstitial cells were determined from electron micrographs taken at a magnification of $\times 2100$, using a Reichert MOP AM02 image-analysing device. The distribution frequency of the size of the lipid droplets was then calculated and the data are presented in histogram form.

The data are shown as means \pm s.e.m. and the statistical significance of differences between groups was analysed using an analysis of variance.

\section{Results}

$\mathrm{NIH}-\mathrm{oFSH}-\mathrm{SI3}$

The effects upon the ovarian follicle population of twice daily injections of various doses of $\mathrm{NIH}-\mathrm{oFSH}-\mathrm{S} 13$ for 4 days are shown in Table 1 . The dose of $600 \mathrm{ng}$ had no significant effect upon

Table 1. The effects of twice daily injection of NIH-oFSH-S13 for 4 days upon the ovarian follicle population and uterine weight in hypogonadal female mice

\begin{tabular}{|c|c|c|c|c|c|c|c|c|c|}
\hline \multirow[b]{2}{*}{ Dose } & \multirow{2}{*}{$\begin{array}{l}\text { No. of } \\
\text { mice }\end{array}$} & \multicolumn{7}{|c|}{ Follicle type } & \multirow{2}{*}{$\begin{array}{l}\text { Uterine wt } \\
\quad(\mathrm{mg})\end{array}$} \\
\hline & & $3 b$ & 4 & $5 a$ & $5 b$ & 6 & 7 & 8 & \\
\hline 0 (hpg) & 5 & $\begin{array}{c}15 \cdot 2 \pm \\
3 \cdot 0\end{array}$ & $\frac{11 \cdot 0 \pm}{3 \cdot 3} \pm$ & $\begin{array}{l}4.2 \pm \\
1.5\end{array}$ & $\begin{array}{l}2 \cdot 3 \pm \\
0.7\end{array}$ & $\begin{array}{l}0.2 \pm \\
0.2\end{array}$ & 0 & 0 & $\begin{array}{l}4.2 \pm \\
0.6\end{array}$ \\
\hline $600 \mathrm{ng}$ & 5 & $\begin{array}{c}13 \cdot 8 \pm \\
2.5\end{array}$ & $\begin{array}{l}8 \cdot 2 \pm \\
2 \cdot 1\end{array}$ & $\begin{array}{l}2 \cdot 8 \pm \\
0.9\end{array}$ & $\begin{array}{l}2 \cdot 3 \pm \\
1 \cdot 2\end{array}$ & 0 & 0 & 0 & $\begin{array}{l}3 \cdot 8 \pm \\
0 \cdot 4\end{array}$ \\
\hline $\mathrm{I} \mu \mathrm{g}$ & 5 & $\begin{array}{l}32 \cdot 3 \pm \\
6 \cdot 1 *\end{array}$ & $\begin{array}{c}13 \cdot 2 \pm \\
3 \cdot 3\end{array}$ & $\begin{array}{l}3 \cdot 0 \pm \\
1 \cdot 0\end{array}$ & $\begin{array}{l}3.5 \pm \\
1.8\end{array}$ & $\begin{array}{l}1 \cdot 3 \pm \\
1 \cdot 0\end{array}$ & $\begin{array}{l}2 \cdot 0 \pm \\
0 \cdot 9\end{array}$ & $\begin{array}{l}0.2 \pm \\
0.2\end{array}$ & $\begin{array}{l}5 \cdot 2 \pm \\
0.6\end{array}$ \\
\hline $3 \mu \mathrm{g}$ & 4 & $\begin{array}{l}33 \cdot 5 \pm \\
5 \cdot 7^{*}\end{array}$ & $\begin{array}{c}12 \cdot 3 \pm \\
2 \cdot 8\end{array}$ & $\begin{array}{l}5 \cdot 8 \pm \\
2 \cdot 3\end{array}$ & $\begin{array}{l}2 \cdot 8 \pm \\
0 \cdot 9\end{array}$ & $\begin{array}{l}2 \cdot 5 \pm \\
0.6 * *\end{array}$ & $\begin{array}{l}1 \cdot 8 \pm \\
1 \cdot 0^{* *}\end{array}$ & $\begin{array}{l}6.5 \pm \\
1.7^{* *}\end{array}$ & $\begin{array}{c}25 \cdot 2 \pm \\
8 \cdot 0^{* *}\end{array}$ \\
\hline $6 \mu \mathrm{g}$ & 5 & $\begin{array}{l}31.2 \pm \\
5.9 *\end{array}$ & $\begin{array}{l}3 \cdot 2 \pm \\
0.7\end{array}$ & $\begin{array}{l}5 \cdot 0 \pm \\
1 \cdot 6\end{array}$ & $\begin{array}{l}2 \cdot 4 \pm \\
1 \cdot 3\end{array}$ & $\begin{array}{l}0.6 \pm \\
0.4\end{array}$ & $\begin{array}{l}0.4 \pm \\
0.4\end{array}$ & $\begin{array}{l}3 \cdot 6 \pm \\
1 \cdot 6^{*}\end{array}$ & $\begin{array}{c}37 \cdot 4 \pm \\
4 \cdot 8^{* *}\end{array}$ \\
\hline $12 \mu \mathrm{g}$ & 5 & $\begin{array}{l}54 \cdot 6 \pm \\
6 \cdot 3^{* * * *}\end{array}$ & $\begin{array}{l}9 \cdot 4 \pm \\
2 \cdot 1\end{array}$ & $\begin{array}{l}5 \cdot 2 \pm \\
2 \cdot 1\end{array}$ & $\begin{array}{l}4 \cdot 4 \pm \\
2 \cdot 0\end{array}$ & $\begin{array}{l}1.6 \pm \\
0.4\end{array}$ & $\begin{array}{l}2 \cdot 4 \pm \\
1 \cdot 2^{*}\end{array}$ & $\begin{array}{l}2 \cdot 8 \pm \\
0 \cdot 8^{*}\end{array}$ & $\begin{array}{r}44 \cdot 9 \pm \\
4 \cdot 4^{* * *}\end{array}$ \\
\hline
\end{tabular}

Compared with untreated $h p g$ females: ${ }^{*} P<0.05 ;{ }^{* *} P<0.01 ;{ }^{* * *} P<0.001$. 
Table 2. The effects of twice daily injection of NIH-oFSH-S15 for 5 days upon the ovarian follicle population and uterine weight in hypogonadal female mice

\begin{tabular}{|c|c|c|c|c|c|c|c|c|c|}
\hline \multirow[b]{2}{*}{ Dose } & \multirow{2}{*}{$\begin{array}{l}\text { No. of } \\
\text { mice }\end{array}$} & \multicolumn{7}{|c|}{ Follicle type } & \multirow{2}{*}{$\begin{array}{l}\text { Uterine wt } \\
\text { (mg) }\end{array}$} \\
\hline & & $3 b$ & 4 & $5 a$ & $5 b$ & 6 & 7 & 8 & \\
\hline $0(h p g)$ & 5 & $\begin{array}{c}15 \cdot 2 \pm \\
3.0\end{array}$ & $\begin{array}{c}11 \cdot 0 \pm \\
3.3\end{array}$ & $\begin{array}{l}4 \cdot 2 \pm \\
1.5\end{array}$ & $\begin{array}{l}2.3 \pm \\
0.7\end{array}$ & $\begin{array}{l}0.2 \pm \\
0.2\end{array}$ & 0 & 0 & $\begin{array}{l}4 \cdot 2 \pm \\
0 \cdot 6\end{array}$ \\
\hline $600 \mathrm{ng}$ & 8 & $\begin{array}{c}14 \cdot 8 \pm \\
2 \cdot 2\end{array}$ & $\begin{array}{c}16 \cdot 0 \pm \\
1 \cdot 2\end{array}$ & $\begin{array}{l}4 \cdot 4 \pm \\
1 \cdot 0\end{array}$ & $\begin{array}{l}3.6 \pm \\
0.9\end{array}$ & $\begin{array}{l}0.6 \pm \\
0.3\end{array}$ & 0 & $\begin{array}{l}0.3 \pm \\
0.2\end{array}$ & $\begin{array}{l}5 \cdot 4 \pm \\
0.5\end{array}$ \\
\hline $1 \mu \mathrm{g}$ & 11 & $\begin{array}{c}17.9 \pm \\
2.0\end{array}$ & $\begin{array}{c}14 \cdot 5 \pm \\
2 \cdot 5\end{array}$ & $\begin{array}{l}4.7 \pm \\
0.8\end{array}$ & $\begin{array}{l}3.5 \pm \\
0.7\end{array}$ & $\begin{array}{l}0.8 \pm \\
0.3\end{array}$ & $\begin{array}{l}0.3 \pm \\
0.2\end{array}$ & $\begin{array}{l}0.3 \pm \\
0.2\end{array}$ & $\begin{array}{l}7.3 \pm \\
0.7\end{array}$ \\
\hline $2 \mu \mathrm{g}$ & 9 & $\begin{array}{c}27 \cdot 3 \pm \\
3 \cdot 0^{*}\end{array}$ & $\begin{array}{r}10 \cdot 2 \pm \\
2 \cdot 7\end{array}$ & $\begin{array}{l}5.7 \pm \\
1.6\end{array}$ & $\begin{array}{l}3.6 \pm \\
0.6\end{array}$ & $\begin{array}{l}3 \cdot 1 \pm \\
1 \cdot 0^{* *}\end{array}$ & $\begin{array}{l}1 \cdot 8 \pm \\
0 \cdot 5^{* *}\end{array}$ & $\begin{array}{l}3 \cdot 7 \pm \\
1 \cdot 4^{* *}\end{array}$ & $\begin{array}{c}29 \cdot 8 \pm \\
5 \cdot 9^{* *}\end{array}$ \\
\hline $3 \mu \mathrm{g}$ & 11 & $\begin{array}{c}31 \cdot 8 \pm \\
4 \cdot 3^{* *}\end{array}$ & $\begin{array}{c}13 \cdot 3 \pm \\
1.5\end{array}$ & $\begin{array}{l}4 \cdot 8 \pm \\
1 \cdot 2\end{array}$ & $\begin{array}{l}2.6 \pm \\
0.8\end{array}$ & $\begin{array}{l}2 \cdot 0 \pm \\
0 \cdot 4\end{array}$ & $\begin{array}{l}1 \cdot 9 \pm \\
0 \cdot 4^{* * *}\end{array}$ & $\begin{array}{l}4 \cdot 2 \pm \\
0 \cdot 8^{* *}\end{array}$ & $\begin{array}{l}50 \cdot 1 \pm \\
7 \cdot 1^{* * *}\end{array}$ \\
\hline $6 \mu \mathrm{g}$ & 4 & $\begin{array}{l}37 \cdot 0 \pm \\
3 \cdot 8^{* *}\end{array}$ & $\begin{array}{l}7 \cdot 0 \pm \\
2 \cdot 4\end{array}$ & $\begin{array}{l}2 \cdot 8 \pm \\
0 \cdot 3\end{array}$ & $\begin{array}{l}3 \cdot 0 \pm \\
0 \cdot 8\end{array}$ & $\begin{array}{l}1.3 \pm \\
0.8\end{array}$ & $\begin{array}{l}0.5 \pm \\
0.5\end{array}$ & $\begin{array}{l}3 \cdot 3 \pm \\
0 \cdot 8^{* *}\end{array}$ & $\begin{array}{c}62 \cdot 0 \pm \\
4 \cdot 9^{* * *}\end{array}$ \\
\hline $12 \mu \mathrm{g}$ & 4 & $\begin{array}{l}38 \cdot 0 \pm \\
7 \cdot 8^{* *}\end{array}$ & $\begin{array}{c}10.5 \pm \\
3.9\end{array}$ & $\begin{array}{l}6.8 \pm \\
3.6\end{array}$ & $\begin{array}{l}2 \cdot 0 \pm \\
0.4\end{array}$ & $\begin{array}{l}4 \cdot 0 \pm \\
2 \cdot 1^{* *}\end{array}$ & $\begin{array}{l}1.1 \pm \\
0.6\end{array}$ & $\begin{array}{l}4 \cdot 0 \pm \\
1 \cdot 1^{* *}\end{array}$ & $\begin{array}{l}59 \cdot 4 \pm \\
16 \cdot 2^{* * *}\end{array}$ \\
\hline
\end{tabular}

Compared with untreated $h p g$ females: ${ }^{*} P<0.05 ;{ }^{* *} P<0.01 ;{ }^{* * *} P<0.001$.

the follicle population, whereas although there were no significant changes in the number of medium-sized follicles, $1 \mu \mathrm{g}$ increased the number of type $3 \mathrm{~b}$ follicles and resulted in the formation of type 7 antral follicles, which are never seen in the ovaries of untreated $h p g$ mice. The effects of $3 \mu \mathrm{g}$ were similar, but there was clear stimulation of antral follicle development. There was no significant difference between the number of type $3 \mathrm{~b}$ follicles produced by injection of 1,3 or $6 \mu \mathrm{g}$ $\mathrm{FSH}-\mathrm{S} 13$, but $12 \mu \mathrm{g}$ produced a significantly greater increase in the number of type $3 \mathrm{~b}$ follicles compared with any other treatment with FSH-S13 $(P<0.05)$. None of the treatments with NIHoFSH-S13 resulted in significant changes in the medium-sized follicle population and none of the treatments produced corpora lutea. However, the incidence of atretic large follicles was increased in animals injected with doses greater than $1 \mu \mathrm{g}$.

The vagina of 4 out of 6 animals injected with $3 \mu \mathrm{g}$ FSH had opened and showed a pro-oestrous smear at the end of the treatment period. Vaginal opening occurred in all the animals injected with 6 or $12 \mu \mathrm{g}$, and in all cases the smear was pro-oestrous at the time of killing. The uterine weights of these animals are also shown in Table 1.

\section{NIH-oFSH-S15}

The effects upon the ovarian follicle population of twice daily injections of NIH-oFSH-S15 are shown in Table 2. The injection period was increased to 5 days because it was felt that this might produce a more consistent response within each group. Doses of $600 \mathrm{ng}$ and $1 \mu \mathrm{g}$ had no significant effect upon the follicle population, whilst doses of $2 \mu \mathrm{g}$ and above increased both the number of early growing follicles and stimulated antral follicle formation. The numbers of type $3 \mathrm{~b}$ and type 8 follicles produced by injection of FSH-S15 were not significantly different from the numbers produced by FSH-S13.

The uterine weights in these animals (Table 2) were similar to those in animals injected with $\mathrm{FSH}-\mathrm{S} 13$. Doses greater than $2 \mu \mathrm{g}$ produced significant increases in the uterine weight and the higher doses of 3,6 and $12 \mu \mathrm{g}$ resulted in a uterine weight which was significantly greater than that produced by $2 \mu \mathrm{g}(P<0.01)$.

The effects upon the ovary of $3 \mu \mathrm{g}$ FSH-S15 were further characterized by an ultrastructural study. This dose was chosen for more detailed studies as it was the lowest effective dose which 

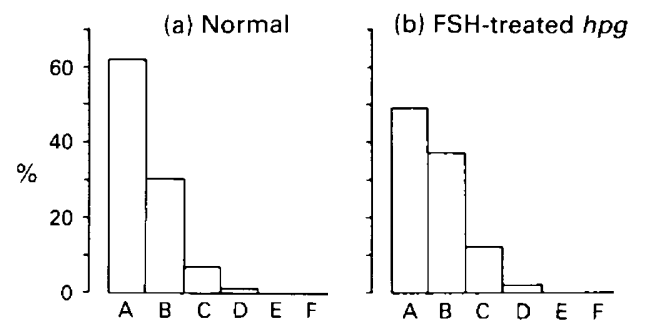

(c) Untreated hpg

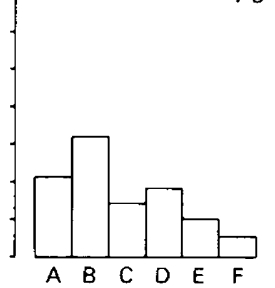

Fig. 1. The size distribution of interstitial cell lipid droplets in (a) normal female mice, (b) female $h p g$ mice treated with $3 \mu \mathrm{g}$ FSH twice daily for 5 days, and (c) untreated $h p g$ female mice. $A=0-0.3 \mu \mathrm{m}^{2}, B=0.3-0.6 \mu \mathrm{m}^{2}, \mathrm{C}=0.6-0.9 \mu \mathrm{m}^{2}, \mathrm{D}=0.9-1.2 \mu \mathrm{m}^{2}, \mathrm{E}=1.2-1.5 \mu \mathrm{m}^{2}$, $F=1.5-1.8 \mu \mathrm{m}^{2}$.

produced an increase in the size of the growing follicle pool, healthy ripe follicles and significant ovarian endocrine activity as determined by the increase in uterine weight.

The major structural changes within the ovary as a result of injection of $3 \mu \mathrm{g} \mathrm{FSH}-\mathrm{S} 15$ were the production of large antral follicles and increased development of the interstitial tissue. Ultrastructurally, the large follicles appeared to be no different from the large follicles present in ovaries from normal animals. The mean granulosa cell area was not significantly different in treated animals $\left(41.9 \pm 2.2 \mu \mathrm{m}^{2}\right)$ from that in normal mice $\left(47.3 \pm 7 \cdot 1 \mu \mathrm{m}^{2}\right)$, and no differences in the size and distribution of organelles were observed. The thecal cell layers also appeared similar to those in normal animals.

The overall amount of the stromal tissue was increased by injection of $3 \mu \mathrm{g} \mathrm{FSH-S15}$ and the interstitial cells showed ultrastructural changes, perhaps the most prominent of which was a change in the size of the intracellular lipid droplets. The ovaries of untreated $h p g$ females contain a small number of large lipid droplets, the size distribution of which is shown in Fig. 1. Treatment with $3 \mu \mathrm{g}$ FSH-S15 produced a redistribution in the size of these droplets, whilst also increasing their total number; however, the number and size of the droplets was still not the same as that seen in normal animals (Fig. 1). The effect of injection of $2 \mu \mathrm{g}$ FSH-S15 on the interstitial cells was similar to that of $3 \mu \mathrm{g} \mathrm{FSH}-\mathrm{S} 15$.

\section{LER 8/116 hFSH}

The effects upon the ovarian follicle population are shown in Table 3. Doses of 3 and $6 \mu \mathrm{g}$ increased the number of type $3 \mathrm{~b}$ follicles and stimulated antral follicle development, but had relatively little effect upon the medium-sized follicles. The increase in the size of the growing follicle population and the number of antral follicles produced was similar to that seen in animals treated with ovine FSH (Tables 1 \& 2). The effects upon uterine weights (Table 3) were similar to those with sheep FSH, with 3 and $6 \mu \mathrm{g}$ producing a significant increase compared to untreated animals.

\section{$N I H \sim O L H-S 24$}

The effects on the ovarian follicle population of twice daily injections of NIH-oLH-S24 for 5 days are shown in Table 4 . Neither $60 \mathrm{ng}$ nor $2 \mu \mathrm{g}$ had any significant effect upon the follicle population, and antral follicles were not formed. These doses also had no significant effect upon the uterine weight (Table 4).

\section{NIH-oFSH-S15 combined with NIH-oFSH-S24}

As shown in Table 4, neither dose of LH in combination with $600 \mathrm{ng}$ FSH had any significant effect upon the follicle population and antral follicles were not formed. When $2 \mu \mathrm{g} \mathrm{FSH}-\mathrm{S} 15$ were 
Table 3. The effects of twice daily injection of LER $8 / 116 \mathrm{hFSH}$ for 4 days upon the ovarian follicle population and uterine weight in hypogonadal female mice

\begin{tabular}{lccccccccc}
\hline & & \multicolumn{7}{c}{ Follicle type } \\
Dose & $\begin{array}{c}\text { No. of } \\
\text { mice }\end{array}$ & $3 \mathrm{~b}$ & 4 & $5 \mathrm{a}$ & $5 \mathrm{~b}$ & 6 & 7 & 8 & $\begin{array}{c}\text { Uterine wt } \\
(\mathrm{mg})\end{array}$ \\
\cline { 3 - 9 } $0(\mathrm{hpg})$ & 5 & $15 \cdot 2 \pm$ & $11 \cdot 0 \pm$ & $4 \cdot 2 \pm$ & $2 \cdot 3 \pm$ & $0 \cdot 2 \pm$ & 0 & 0 & $4 \cdot 2 \pm$ \\
& & $3 \cdot 0$ & $3 \cdot 3$ & $1 \cdot 5$ & $0 \cdot 7$ & $0 \cdot 2$ & & & $0 \cdot 6$ \\
$500 \mathrm{ng}$ & 5 & $30 \cdot 0 \pm$ & $14 \cdot 0 \pm$ & $5 \cdot 6 \pm$ & $2 \cdot 6 \pm$ & $1 \cdot 2 \pm$ & $0 \cdot 2 \pm$ & 0 & $4 \cdot 4 \pm$ \\
& & $5 \cdot 5$ & $5 \cdot 0$ & $2 \cdot 6$ & $1 \cdot 1$ & $0 \cdot 5$ & $0 \cdot 2$ & & $0 \cdot 4$ \\
$1 \mu \mathrm{g}$ & 7 & $28 \cdot 3 \pm$ & $12 \cdot 1 \pm$ & $7 \cdot 1 \pm$ & $5 \cdot 4 \pm$ & $2 \cdot 7 \pm$ & $2 \cdot 7 \pm$ & $4 \cdot 4 \pm$ & $7 \cdot 7 \pm$ \\
& & $2 \cdot 4^{*}$ & $2 \cdot 2$ & $1 \cdot 4$ & $1 \cdot 4$ & $1 \cdot 0^{*}$ & $1 \cdot 1$ & $1 \cdot 1^{* *}$ & $1 \cdot 2$ \\
$3 \mu \mathrm{g}$ & 9 & $37 \cdot 2 \pm$ & $11 \cdot 0 \pm$ & $5 \cdot 0 \pm$ & $2 \cdot 8 \pm$ & $2 \cdot 1 \pm$ & $1 \cdot 4 \pm$ & $4 \cdot 0 \pm$ & $19 \cdot 2 \pm$ \\
& & $4 \cdot 5^{* *}$ & $1 \cdot 6$ & $1 \cdot 1$ & $0 \cdot 7$ & $0 \cdot 6^{*}$ & $0 \cdot 5^{* *}$ & $1 \cdot 2^{* *}$ & $5 \cdot 3^{*}$ \\
$6 \mu \mathrm{g}$ & 9 & $48 \cdot 1 \pm$ & $7 \cdot 0 \pm$ & $4 \cdot 4 \pm$ & $4 \cdot 2 \pm$ & $2 \cdot 1 \pm$ & $2 \cdot 0 \pm$ & $3 \cdot 9 \pm$ & $45 \cdot 2 \pm$ \\
& & $5 \cdot 8^{* *}$ & $1 \cdot 3$ & $1 \cdot 0$ & $0 \cdot 6$ & $0 \cdot 6^{*}$ & $0 \cdot 6^{* *}$ & $0 \cdot 6^{* *}$ & $5 \cdot 9^{* * *}$ \\
\hline
\end{tabular}

Compared with untreated $h p g$ females: ${ }^{*} P<0.05 ;{ }^{* *} P<0.01 ;{ }^{* * *} P<0.001$.

Table 4. The effects of twice daily injection of NIH-oLH-S24 with and without NIH-oFSH-S15 for 4 days upon the ovarian follicle population and uterine weight in hypogonadal female mice

\begin{tabular}{|c|c|c|c|c|c|c|c|c|c|}
\hline \multirow[b]{2}{*}{ Dose } & \multirow{2}{*}{$\begin{array}{l}\text { No. of } \\
\text { mice }\end{array}$} & \multicolumn{7}{|c|}{ Follicle type } & \multirow{2}{*}{$\begin{array}{l}\text { Uterine wt } \\
(\mathrm{mg})\end{array}$} \\
\hline & & $3 b$ & 4 & $5 \mathrm{a}$ & $5 b$ & 6 & 7 & 8 & \\
\hline 0 (hpg) & 5 & $\begin{array}{c}15 \cdot 2 \pm \\
3 \cdot 0\end{array}$ & $\begin{array}{c}11 \cdot 0 \pm \\
3 \cdot 3\end{array}$ & $\begin{array}{l}4 \cdot 2 \pm \\
1 \cdot 5\end{array}$ & $\begin{array}{l}2 \cdot 3 \pm \\
0 \cdot 7\end{array}$ & $\begin{array}{l}0 \cdot 2 \pm \\
0 \cdot 2\end{array}$ & 0 & 0 & $\begin{array}{l}4 \cdot 2 \pm \\
0 \cdot 6\end{array}$ \\
\hline $60 \mathrm{ng} \mathrm{LH}$ & 7 & $\begin{array}{c}18 \cdot 0 \pm \\
2.5\end{array}$ & $\begin{array}{l}8 \cdot 3 \pm \\
0 \cdot 7\end{array}$ & $\begin{array}{l}3 \cdot 1 \pm \\
1 \cdot 1\end{array}$ & 0 & 0 & 0 & 0 & $\begin{array}{l}5 \cdot 3 \pm \\
0 \cdot 4\end{array}$ \\
\hline $2 \mu \mathrm{g} \mathrm{LH}$ & 7 & $\begin{array}{c}17.2 \pm \\
1.9\end{array}$ & $\begin{array}{l}9 \cdot 1 \pm \\
1 \cdot 5\end{array}$ & $\begin{array}{l}4 \cdot 6 \pm \\
0.9\end{array}$ & $\begin{array}{l}1 \cdot 7 \pm \\
0.5\end{array}$ & 0 & 0 & 0 & $\begin{array}{l}5 \cdot 4 \pm \\
0 \cdot 4\end{array}$ \\
\hline $\begin{array}{l}600 \mathrm{ng} \text { FSH }+ \\
60 \mathrm{ng} \mathrm{LH}\end{array}$ & 10 & $\begin{array}{c}17.6 \pm \\
1.6\end{array}$ & $\begin{array}{l}8 \cdot 8 \pm \\
1 \cdot 5\end{array}$ & $\begin{array}{l}3 \cdot 7 \pm \\
0 \cdot 7\end{array}$ & $\begin{array}{l}2 \cdot 4 \pm \\
0 \cdot 7\end{array}$ & $\begin{array}{l}0.4 \pm \\
0.2\end{array}$ & 0 & 0 & $\begin{array}{l}5 \cdot 8 \pm \\
0 \cdot 4\end{array}$ \\
\hline $\begin{array}{l}600 \mathrm{ng} \mathrm{FSH}+ \\
2 \mu \mathrm{g} \mathrm{LH}\end{array}$ & 8 & $\begin{array}{c}22.0 \pm \\
3.9\end{array}$ & $\begin{array}{l}9 \cdot 5 \pm \\
2 \cdot 0\end{array}$ & $\begin{array}{l}4 \cdot 8 \pm \\
0 \cdot 8\end{array}$ & $\begin{array}{l}2 \cdot 9 \pm \\
0.7\end{array}$ & 0 & 0 & 0 & $\begin{array}{l}7 \cdot 3 \pm \\
0 \cdot 8\end{array}$ \\
\hline $\begin{array}{l}2 \mu \mathrm{g} \mathrm{FSH}+ \\
60 \mathrm{ng} \mathrm{LH}\end{array}$ & 10 & $\begin{array}{c}44 \cdot 6 \pm \\
5 \cdot 3\end{array}$ & ${ }_{1.6}^{10 \cdot 1} \pm$ & $\begin{array}{l}5 \cdot 1 \pm \\
1 \cdot 1\end{array}$ & $\begin{array}{l}4 \cdot 6 \pm \\
1 \cdot 1\end{array}$ & $\begin{array}{l}1 \cdot 2 \pm \\
0.5\end{array}$ & $\begin{array}{l}2 \cdot 0 \pm \\
0 \cdot 7\end{array}$ & $\begin{array}{l}2 \cdot 0 \pm \\
0 \cdot 6\end{array}$ & $\frac{26 \cdot 7}{5 \cdot 5} \pm$ \\
\hline $\begin{array}{l}2 \mu \mathrm{g} \mathrm{FSH}+ \\
20 \mu \mathrm{g} \mathrm{LH}\end{array}$ & 9 & $\begin{array}{c}53 \cdot 7 \pm \\
9 \cdot 6\end{array}$ & $\begin{array}{c}11 \cdot 2 \pm \\
2 \cdot 1\end{array}$ & $\begin{array}{l}5 \cdot 7 \pm \\
0 \cdot 9\end{array}$ & $\begin{array}{l}4 \cdot 7 \pm \\
1 \cdot 0\end{array}$ & $\begin{array}{l}1 \cdot 1 \pm \\
0 \cdot 4\end{array}$ & $\begin{array}{l}0 \cdot 8 \pm \\
0 \cdot 2\end{array}$ & $\begin{array}{l}2 \cdot 0 \pm \\
0 \cdot 8\end{array}$ & $\begin{array}{c}14 \cdot 4 \pm \\
2 \cdot 6\end{array}$ \\
\hline
\end{tabular}

given in combination with $60 \mathrm{ng} \mathrm{LH}-\mathrm{S} 24$ there was a significant increase $(P<0.01)$ in the number of type $3 \mathrm{~b}$ follicles compared with $2 \mu \mathrm{g}$ FSH alone, but the effect on antral follicle production was no different from that with $2 \mu \mathrm{g}$ FSH-S15 alone (Table 2). The effects of $2 \mu \mathrm{g} \mathrm{LH}-\mathrm{S} 24$ in combination with $2 \mu \mathrm{g}$ FSH-S1 5 were not significantly different from those of $60 \mathrm{ng} \mathrm{LH}+2 \mu \mathrm{g} \mathrm{FSH}-\mathrm{S} 15$ in terms of healthy growing follicles, but the higher dose of LH also produced luteinized follicles in 5 out of 9 animals. These are follicles in which the granulosa cells appear to have undergone luteinization, but which still contain the oocyte within an antrum. They have been reported to be formed by a ripe follicle responding to a sub-threshold ovulatory dose of LH or by an immature follicle responding prematurely to an ovulatory dose of LH (Holsinger \& Everett, 1970; Peters \& McNatty, 1980).

Neither dose of LH in combination with $600 \mathrm{ng} \mathrm{FSH-S15}$ had a significant effect on the uterine weight (Table 4). Addition of $60 \mathrm{ng} \mathrm{LH}$ to $2 \mu \mathrm{g}$ FSH-S15 caused no further increase in the uterine 
weight above that produced by $2 \mu \mathrm{g}$ FSH alone (Tables $2 \& 4$ ), but addition of $2 \mu \mathrm{g} \mathrm{LH}$ to $2 \mu \mathrm{g}$ FSH-S15 produced a significantly smaller $(P<0.001)$ increase in uterine weight than that produced by $2 \mu \mathrm{g}$ FSH alone (Tables $2 \& 4$ ).

Injection of $60 \mathrm{ng} \mathrm{LH}$ alone or in combination with $600 \mathrm{ng} \mathrm{FSH}-\mathrm{S} 15$ had no significant effect upon the number or size of the interstitial cell lipid droplets, whilst the effect of $60 \mathrm{ng} \mathrm{LH}$ in combination with $2 \mu \mathrm{g}$ FSH-S15 was similar to that of $2 \mu \mathrm{g}$ FSH-S15 alone. A dose of $2 \mu \mathrm{g} \mathrm{LH}$ produced a marked redistribution in the size of the droplets, but their size was still not the same as that seen in normal females. The addition of $600 \mathrm{ng}$ FSH or $2 \mu \mathrm{g} \mathrm{FSH}$ had no significant effect upon the size distribution of droplets produced by injection of $2 \mu \mathrm{g} \mathrm{LH}$.

\section{Discussion}

Hypogonadal mice are deficient in hypothalamic GnRH (Cattanach et al., 1977) as a result of a deletion in the GnRH gene (Mason et al., 1986a) and have an associated reduction in pituitary and plasma gonadotrophin concentrations. Adult animals of both sexes are severely hypogonadal, but the ovaries are capable of apparently normal function when transplanted into a normal endocrine environment (Bamber et al., 1980) or when the genetic defect is corrected (Mason et al., 1986b).

All three preparations of FSH produced an increase in the number of type $3 \mathrm{~b}$ follicles, which are the earliest of the growing follicles. This is consistent with our previous observations that a deficiency of gonadotrophins results in a reduction in the size of the population of growing follicles as a result of a reduction in the rate at which non-growing follicles enter the pool of growing follicles (Halpin et al., 1986a, b). The mechanism of the effect is unclear, but there is evidence that it is due principally to a reduction in the number of follicles lost to atresia rather than to a stimulation of growth per se (Halpin et al., 1986a). No significant increases in the number of medium-sized follicles were observed with any of the treatments, but given the increase in the initiation of follicle growth and the formation of antral follicles, it is possible that the growth of medium-sized follicles may be stimulated without an observable change in the number of these follicles.

All three preparations of FSH also stimulated antral follicle development and this response showed saturation, at the same dose despite the fact that the reported activity of LER $8 / 116$ is over twice that of NIH-FSH-S13, with NIH-FSH-S15 having an intermediate activity. Moreover, doses of $6 \mu \mathrm{g}$ and above produced approximately the same number of antral follicles as that found in normal adult females (Halpin et al., 1986b). A superovulatory response did not occur with these preparations, unlike PMSG which has been shown to stimulate superovulation in hpg females (Ward, 1980). This may have been due to the relative purity of the FSH preparations used in these studies, since PMSG has a dual FSH/LH like activity (Ben-Or, 1970; Dorfman, 1972); however, superovulation was not produced by the combined injection of FSH and LH and therefore this phenomenon may, at least in part, reflect the longer half-life of PMSG (Ben-Or, 1972).

The observation that FSH stimulated the development of antral follicles is in agreement with the work of Hirshfield \& Midgley (1978) in cyclic rats, but seems to contradict the findings of Richards et al. (1980) who reported that it was a change in the tonic secretion of LH which initiated preovulatory follicle development in pregnant rats. It may be that both FSH and LH can act as triggers for this process, or that the increase in circulating LH concentrations caused by the LH contamination of the FSH preparations was sufficient to stimulate antral follicle development. If the contaminating LH was important, then the threshold at which the ovary responded to the injection of FSH may actually have been determined by the amount of LH injected rather than the amount of FSH, and lower doses of FSH should have been effective if combined with more $\mathrm{LH}$. This was not the case. Neither the low dose of LH of $60 \mathrm{ng} \mathrm{NIH-LH-S24} \mathrm{(which} \mathrm{was} \mathrm{equivalent} \mathrm{to}$ the contaminating dose of $\mathrm{LH}$ in $3 \mu \mathrm{g} \mathrm{FSH}$ ), nor the higher dose of $\mathrm{LH}$ (which was chosen on the basis of a dose-response analysis of its stimulation of seminal vesicle growth in males (unpublished observations)) lowered the threshold of the ovarian response to FSH. 
Although these studies do not completely eliminate the possibility that $\mathrm{LH}$ has a permissive effect, they suggest that, in mice at least, an increase in the plasma LH concentration, on its own, is not sufficient to stimulate antral follicle development, and FSH is also required for this process, as was suggested by Lostroh \& Johnson (1966). However, in combination with a dose of FSH which itself stimulated follicle development, LH was capable of synergism, increasing the number of growing follicles.

All three preparations of FSH produced a significant increase in the uterine weight and stimulated vaginal opening, suggesting that the ovaries in these animals were secreting steroids. In view of the high degree of purity of the preparations used in terms of LH contamination, this is somewhat surprising as both FSH and $\mathrm{LH}$ are thought to be required for steroidogenesis, with $\mathrm{LH}$ stimulating the production of androgens by the thecal cells, and FSH stimulating their aromatization by granulosa cells (Armstrong \& Dorrington, 1977). As with the question of the trigger for antral follicle development, it is impossible to rule out completely a contribution from $\mathrm{LH}$ to steroidogenesis. Nevertheless, the LH stimulus, whether endogenous or exogenous, was likely to have been small compared to the FSH stimulation of the granulosa cells. This may have been mitigated by an increased sensitivity to $\mathrm{LH}$, but in the absence of biochemical studies we believe that the ultrastructure of the interstitial cells suggests that LH stimulation was minimal.

In normal mice the size of the interstitial compartment increases with increasing age and this has been attributed to the formation of interstitial cells from follicular cells, largely by the transformation of thecal cells (Peters \& Levy, 1966). They possess LH receptors (Charlton et al., 1982) and resemble typical steroid-secreting cells (Mutta, 1958; Fawcett et al., 1969). Their lipid droplets may contain precursors for steroidogenesis (Stegner, 1970) and changes in the number of lipid droplets have been correlated with gonadotrophic stimulation and steroidogenesis in several species (Barker, 1951; Rennels, 1951; Guraya \& Greenwald, 1964; Nagai et al., 1967).

In our studies, both FSH and LH affected the ultrastructure of the ovarian interstitial cells, but the effects of the hormones were different, with LH giving rise to smaller droplets than FSH. FSH stimulation produced cells quite unlike those seen in normal females and its effects must be regarded as supraphysiological, as well as indirect since these cells do not appear to have FSH receptors (Peters \& McNatty, 1980; Charlton et al., 1982). Moreover, the effects of LH injections and combined injections differed from those of FSH alone, suggesting that the actions of FSH on the interstitial cells were not due to the LH contamination. In fact, the interstitial cells in animals treated with FSH closely resembled those in oestrogen-2 treated animals $(\mathrm{H}$. M. Charlton, unpublished observations), suggesting that the effects of FSH upon these cells may be mediated by oestrogen released from granulosa cells. In normal circumstances, this effect may represent a feedback mechanism to control interstitial cell production of androgens.

We therefore conclude that on its own FSH can increase the rate at which non-growing follicles enter the growing pool and that this is the hormone which is responsible for rescuing medium-sized follicles from atresia, thereby allowing the development of antral follicles. Moreover, these antral follicles appear capable of secreting physiologically significant amounts of oestrogen under the influence of FSH in the absence of a significant LH stimulus.

We thank A. Jones and R. Rees for excellent technical assistance; and Professor L. E. Reichert and NIADDK for donation of the gonadotrophin preparations. These studies were supported by the MRC and the Wellcome Foundation. D.M.G.H. was an MRC scholar.

\section{References}

Armstrong, D.T. \& Dorrington, J.H. (1977) Estrogen biosynthesis in ovaries and testes. Adv. Sex. Horm. Res. 3, 217-258.
Bamber, S., Iddon, C.A., Charlton, H.M. \& Ward, B.J. (1980) Transplantation of the gonads of hypogonadal (hpg) mice. J. Reprod. Fert. 58, 249-252. 
Barker, W.L. (1951) A cytochemical study of lipids in sows' ovaries during the estrous cycle. Endocrinology 48, 772-785.

Ben-Or, S. (1970) Development of the ovary under different experimental conditions. In Gonadotrophins and Ovarian Development, pp. 266-271. Eds W. R. Butt, A. C. Crooke \& M. Ryle. Livingstone, Edinburgh.

Cattanach, B.M., Iddon, C.A., Charlton, H.M., Chiappa, S.A. \& Fink, G (1977) Gonadotrophin-releasing hormone deficiency in a mutant mouse with hypogonadism. Nature, Lond. 269, 338-340.

Charlton, H.M., Parry, D., Halpin, D.M.G. \& Webb, R. (1982) Distribution of ${ }^{125}$ I-labelled follicle-stimulating hormone and human chorionic gonadotrophin in the gonads of hypogonadal ( $h p g)$ mice. J. Endocr. 93, 247-252.

Dorfman, R.I. (1972) Mechanism of action of gonadotrophins and prolactin. In Biochemical Aciions of Hormones, Vol. II, pp. 295-316. Ed. G. Litwack. Academic Press, London.

Fawcett, D.W., Long, J.A. \& Jones, A.C. (1969) The ultrastructure of endocrine glands. Recent Prog. Horm. Res. 25, 315-380.

Greep, R.O., VanDyke, H.B. \& Chow, B.F. (1942) Gonadotrophins of the swine pituitary. I. Various biochemical effects of purified thylakentrin (FSH) and pure metakentrin (ICSH). Endocrinology 30, 635-649.

Guraya, S.S. \& Greenwald, G.S. (1964) Histochemical studies on the interstitial gland in the rabbit ovary. Am. J. Anat. 114, 495-519.

Halpin, D.M.G., Charlton, H.M. \& Faddy, M.J. (1986a) Effects of gonadotrophin deficiency on follicular development in hypogonadal ( $h p g)$ mice. J. Reprod. Fert. 78, 119-125.

Halpin, D.M.G., Jones, A., Fink, G. \& Charlton, H.M. (1986b) Postnatal ovarian follicle development in hypogonadal ( $h p g$ ) and normal mice and associated changes in the hypothalamic-pituitary ovarian axis. J. Reprod. Fert. 77, 287-296.

Hirshfield, A.N. \& Midgley, A.R. (1978) The role of FSH in the selection of large ovarian follicles in the rat. Biol. Reprod. 19, 606-611.

Holsinger, J.W. \& Everett, J.W. (1970) Ovarian thresholds to exogenous LH at various times of the rat estrous cycle. Endocrinology 86, 257-260.

Lostroh, A.J. \& Johnson, R.E. (1966) Amounts of ICSH and $\mathrm{FSH}$ required for follicular development, uterine growth and ovulation in the hypophysectomized rat. Endocrinology 79, 991-996.

Mason, A.J., Hayflick, J.S., Zoeller, R.T., Young, W.S., Phillips, H.S., Nikolics, K. \& Seeburg, P.H. (1986a) A deletion truncating the gonadotropin-releasing hormone gene is responsible for hypogonadism in the hpg mouse. Science, N.Y. 234, 1366-1371.
Mason, A.J., Pitts, S.L., Nikolics, K., Szonyi, E., Wilcox, J.N., Seeburg, P.H. \& Stewart, T.A. (1986b) The hypogonadal mouse: reproductive functions restored by gene therapy. Science, N.Y. 234, 1372-1378.

Mutta, T. (1958) The fine structure of the interstitial cell in the mouse ovary studied with electron microscopy. Kurume med. J. 5, 167-185.

Nagai, K., Lindlar, F. \& Stolpmann, H.J. (1967) Morphologishe und chemische untersuchungen über die lipoide des hormonal stimulierten ovars der ratte. $Z$. Zellforsch. mikrosk. Anat. 79, 550-561.

Parlow, A.F. (1961) Bioassay of pituitary luteinizing hormone by depletion of ascorbic acid. In Human Pituitary Gonadotrophins, pp. 300-310. Ed. A. Albert. Charles C. Thomas, Springfield.

Pedersen, T. \& Peters, H. (1968) Proposal for a classification of oocytes and follicles in the ovary of the mouse. J. Reprod. Fert. 17, 555-557.

Peters, H. \& Levy, E. (1966) Cell dynamics of the ovarian cycle. J. Reprod. Fert. 11, 227-236.

Peters, H. \& McNatty, K.P. (1980) The Ovary. Granada Publishing, London.

Rennels, E.G. (1951) Influence of hormones on the histochemistry of ovarian interstitial tissue in immature rat. Am. J. Anat. 88, 63-107.

Reichert, L.E. (1967) Selective inactivation of the LH contamination in human pituitary FSH preparations by digestion with alpha-chymotrypsin. J. clin. Endocr. Metab. 27, 1065-1067.

Richards, J.S. (1980) Maturation of ovarian follicles: actions and interactions of pituitary and ovarian hormones on follicular cell differentiation. Physiol. Rev. 60, 51-89.

Richards, J.S., Jonassen, J.A. \& Kersey, K.A. (1980) Evidence that changes in tonic LH secretion determine the growth of preovulatory follicles in the rat. Endocrinology 107, 641-648.

Steelman, S.L. \& Pohley, F.M. (1953) Assay of the follicle stimulating hormone based on augmentation with human chorionic gonadotrophin. Endocrinology $53,604-616$.

Stegner, H.E. (1970) Electron microscope studies of the interstitial tissue in the immature mouse ovary. In Gonadotrophins and Ovarian Development, pp. 232-238. Eds W. R. Butt, A. C. Crooke \& M. Ryle. Livingstone, Edinburgh.

Ward, B.J. (1980) Some aspects of the reproductive physiology and behaviour of the hypogonadal mouse. M.Sc. Thesis. University of Oxford. 